\title{
SANITATION, INTESTINAL INFECTIONS, AND INFANT MORTALITY IN LATE VICTORIAN SYDNEY
}

\author{
by
}

\section{MILTON LEWIS*}

FROM THE viewpoint of community health, the history of the Victorian city in Britain can be regarded as the history of "fever", especially typhoid fever. ${ }^{1}$ The same can properly be said of Victorian Sydney. The introduction of adequate sanitation of the city's environment was an important step in the control of the intestinal infections and the high mortality they produced in infants. Sydney was almost as effective a killer of babies as many other Western cities of the time. ${ }^{2}$

In Sydney, as overseas, diarrhoeal disease significantly contributed to the high infant mortality of the time: in the period 1875-1900, diarrhoeal mortality was almost always greater than thirty per 1,000 births. It was more than thirty-seven per 1,000 in 1901, but had fallen to just over two per 1,000 in 1933. High death rates from diarrhoeal disease were commonly recorded in other cities of Australia and in Europe and North America. In 1891, Professor H. B. Allen of Melbourne wrote that it was "lamentable that the mortality from these diseases should continue so great" and that the incidence should fall chiefly on children. In 1885 the Health Board of the colony of Victoria had drawn attention to the fact that five-sixths of deaths from diarrhoea were of children under five years of age. ${ }^{3}$ In New York City the infant death rate from diarrhoeal disease was over eighty-four per 1,000 in 1885. By 1901 it was down to just under forty-five and was only a little less than eighteen per 1,000 in 1920. ${ }^{4}$ During the 1880s and 1890s London had an average infant death rate from diarrhoea of 23.3 per 1,000 births. The industrial centre, Leicester, had an average of

*Milton Lewis, Ph.D., formerly Research Scholar, Department of History, Research School of Social Sciences, and formerly Tutor, Human Sciences Program, Australian National University, Canberra.

1 G. Rosen, in H. J. Dyos and M. Wolff (editors), The Victorian city. Images and realities, 2 vols., London, Routledge \& Kegan Paul, 1973, vol. 2, p. 629.

2 The infant mortality rates of Sydney were considerably higher than country rates in New South Wales from the 1870s to the early 1900s, and the gap did not disappear until the later 1920s. W. G. Armstrong, Med. J. Aust., October 1939, p. 647. This urban-rural differential obtained in Australia as a whole, and reflected the fact that infectious disease was the predominant cause of infant mortality. H. O. Lancaster, ibid., July 1956, p. 107 . Before the turn of the century, infant death rates tended to be greater in British and European cities than in rural areas. G. Newman, Infant mortality. A social problem, London, Methuen, 1906, pp. 52 and 179-180.

H. B. Allen, Second general report [to the Premier of Victoria], Melbourne, Govt. Printer, 1891, p. 16. Central Board of Health, Report of the Board for 1885, Melbourne, Govt. Printer, 1885, p. 17.

In 1885, per thousand of estimated infant population. E. C. Meyer, Infant mortality in New York City, New York City, Rockefeller Foundation International Health Board, 1921, p. 19. A. V. Hardy, Bull. Wld Hlth Org., 1959, 21 : 312. 


\section{Milton Lewis}

48.4 for the same period, while Preston, Lancashire, returned $60.4 .^{5}$ The average infant mortality of forty-two German cities in 1906 was 198 per 1,000 births, and diarrhoeal conditions accounted for over eighty per cent of deaths: the city of Leipzig had an infant diarrhoeal death rate which was fifty-five per 1,000 in 1900 , but which rose as high as 430 per 1,000 for the summer month of August. The historian of the infant welfare movement in Britain, G. F. McCleary, wrote concerning epidemic diarrhoea, "Its annual visitation was an impressive event, the tragic significance of which it is difficult at this time to realize."6 Dr. G. J. Cuthbert, sometime Director of Infant and Maternal Welfare in New South Wales, wrote about infant mortality in the State, "The greatest over-all improvement in rates from all causes is in the decline of diarrhoea and enteritis, which together, during the first quarter of the [twentieth] century . . . represented a dreaded community scourge with the return of every summer."'

It seems likely that diarrhoeal conditions were an even more significant cause of infant deaths than the vital statistics indicated, since diarrhoeal disease was often linked with wasting states, which themselves might be returned as the cause of death. Modern studies of communities in the Third World have pointed to an interaction between diarrhoea and malnutrition often leading to death. A diarrhoeal attack produces a serious decline in the baby's nutritional status, and a poor nutritional state reduces capacity to resist infection. The term, "weanling diarrhoea", was coined to describe the process in which diarrhoeal disease and malnutrition interact. ${ }^{8}$ I suggest that "weanling diarrhoea" was a considerable infant health problem in Sydney and other cities of the Western world where mortality from diarrhoeal disease was very high in the later nineteenth and early twentieth centuries. ${ }^{9}$

The concept of weanling diarrhoea implies that the mortality associated with diarrhoeal disease may be more extensive than that directly attributed to diarrhoeal conditions. There was a notable proportion of infant deaths returned in the vital statistics of Sydney in the late nineteenth century under "atrophy", "marasmus", and "debility", loose terms implying failure to thrive. ${ }^{10}$

- Sir Arthur Newsholme, Fifty years in public health, London, Allen \& Unwin, 1935, p. 351.

- G. F. McCleary, The maternity and child welfare movement, London, King \& Son, 1935, p. 6.

7 Med. J. Aust., January 1950, p. 76.

${ }^{8}$ See N. S. Scrimshaw, C. E. Taylor and J. E. Gordon, Interactions of nutrition and infection, Geneva, W.H.O., 1968.

- The problem was perhaps not as severe as that experienced in contemporary Third World communities because the infant's post-weaning diet, poor as it often was, was not as deficient in quality. Sydney babies had regular access to fresh or preserved cows' milk, even if this, when finally consumed, was often in a dirty condition. Even so, there is much evidence that the use of nutritionally inferior substitutes for breast-milk was widespread in Sydney as elsewhere in Australia in the late nineteenth century. See M. J. Lewis, "Populate or perish"': aspects of infant and maternal health in Sydney, 1870-1939', Ph.D. thesis, Australian National University, 1976, ch. 2. Widespread resort to patent foods and condensed milks for infant feeding in Britain in the same period is said to have been responsible for a good deal of infantile scurvy and rickets. J. C. Drummond and A. Wilbraham, The Englishman's food. A history of five centuries of English diet, London, Cape, 1939, pp. 449-451. See also I. G. Wickes, Archs Dis. Childh., 1953, 28: 416-422.

${ }_{10}$ R. M. Woodbury, reviewing the causes of infant mortality in eight American cities in 19111916, noted that many deaths of infants older than one month from "debility", "malnutrition", and "marasmus" were classified in the vital statistics under "congenital debility" and so wrongly inflated mortality from causes peculiar to early infancy. Causal factors in infant mortality: a statistical 


\section{Sanitation, intestinal infections, and infant mortality in late Victorian Sydney}

In 1905, Dr. W. G. Armstrong, first medical officer of health for the Sydney metropolitan area and pioneer of systematic infant welfare work in Australasia, pointed out that mortality from convulsions, teething, and atrophy and its synonyms had greatly diminished over the previous thirty years. ${ }^{11}$ These very large falls were inexplicable, Armstrong suggested, unless it were assumed that more accurate diagnosis and certification had resulted in the transfer of most such deaths to another category in the vital statistics, and the only category to which they could reasonably have shifted, given mortality trends, was diarrhoea and enteritis. Further, he offered evidence of close seasonal correlations between the high points in the death rates ascribed to diarrhoea, atrophy, convulsions, and teething. In 1905 W. F. Litchfield, a leading Sydney paediatrician, attributed about fifty per cent of infant deaths in Sydney directly or indirectly to diarrhoeal disease. His clinical experience led him to include deaths from "atrophy" and "dentition" (teething) in the total of diarrhoeal mortality. ${ }^{12}$ It would seem, then, that extensive as the mortality recorded under diarrhoeal disease was, much of the mortality returned under convulsions, atrophy, debility, and marasmus, and probably that returned under dentition, should be added. The combined mortality from these sources constitutes a large proportion of total infant mortality in Sydney in the later nineteenth and early twentieth centuries. Diarrhoeal and associated conditions were terrible reapers of infant life in Sydney, as they appear to have been in many other Western cities of the period.

The general death rate from typhoid in the metropolitan area fluctuated considerably in the late nineteenth century. However, it remained at a high level until the 1890s. In the late 1870 s it reached a high point of more than eighty per 100,000 of population, and it rose even more dramatically in the 1880 s, reaching a maximum of ninety per 100,000 in the middle of the decade. Thereafter there was a very notable decline, and by 1900 it was approximately twenty-three per 100,000 . By 1920 , it was five per 100,000, and a decade later had become a negligible cause of death in Sydney.

The general mortality rate from diarrhoeal disease, particularly relevant to infant, as distinct from adult, mortality, was prone to fluctuate markedly. Like the typhoid

study, Washington, D.C., U.S. Children's Bureau, 1925, p. 6.

${ }_{11}$ See W. G. Armstrong, Trans. Australas. med. Congr., 1905, p. 395. Armstrong introduced the first systematic effort to reduce infant mortality in Sydney in 1903, four years before Dr. Truby King, the internationally-known New Zealand expert on infant care, began his campaign. Armstrong based his approach on the work of English medical officers of health like Dr. Arthur Newsholme, and on that of French infant clinics. Impressed by Newsholme's suggestion that the home was the most common focus of infection in diarrhoeal disease, Armstrong directed his efforts towards providing advice to the mother in the home: the core of instruction was encouragement of breastfeeding, but emphasis was also placed on hygiene. At first a lady health visitor made domiciliary visits in the City. From 1909 the visiting service operated in the working-class inner suburbs adjacent to the City. From 1915 clinics replaced Armstrong's service, after the Minister for Public Health in the State Labour Government, the Hon. Fred. Flowers, decided to develop infant welfare work.

12 W. F. Litchfield, Trans. Australas. med. Congr., 1905, p. 421. Later, he suggested that among the acute illnesses which precipitated convulsive states in infants, the most significant was summer diarrhoea. J. Univ. Sydney med. Soc., November 1909, p. 105. Dr. W. S. Byrne wrote in 1904 that many deaths indirectly due to gastroenteritis were returned under other causes like "dentition" and "convulsions", "... so that we may conclude that the deaths from gastro-enteritis are more numerous by a long way than is set down in the returns of the Registrar-General." Australas. med. Gaz., February 1904, p. 56. 


\section{Milton Lewis}

death rate, it reached its apogee in the mid-1880s, climbing to more than 360 per 100,000 of population. While fluctuations occurred subsequently, the downward trend is again evident. The movement in the diarrhoeal mortality rate closely followed the movement in the typhoid rate, the great difference being that the decline in diarrhoeal mortality lagged behind the decline in mortality from typhoid. Thus, it is argued, improvement in the sanitary environment of the metropolis operated favourably, powerfully, but unequally on the two rates.

It seems that other significant factors influenced the diarrhoeal rate. Dr. J. H. L. Cumpston explained the lag of the diarrhoeal rate as follows: "The reason for this ... [is] the incidence of these diseases has been amongst young children. In this section of the population other measures of direct application are necessary besides those measures of general sanitation which have been sufficient to control typhoid fever ... several years must elapse before the influence of all the infant welfare work is generally appreciated in the statistics of mortality."18

My argument is that better nutrition and domestic hygiene have been important influences on infant diarrhoeal mortality. Any improvement in environmental sanitation, while important, must be supplemented by advances in these areas, if the death rate from infant diarrhoeal disease is to be really affected. And, commencing in the years before World War I, systematic infant welfare work in Sydney did attack problems in both these areas. By 1911, health visitors engaged in such work were reaching about 4,500 newborn babies a year, approximately twenty per cent of all births registered in the metropolitan area in that year. Morever, the campaign was directed at the social class most vulnerable to mortality from infant diarrhoea and associated conditions: it reached the poor of the City of Sydney first, and soon after was extended to the working-class inner suburbs. ${ }^{14}$

There was great improvement in the sanitary condition of the city in the last thirty years of the nineteenth century. The water supply was reliable after the later 1880s. The sewage disposal situation steadily improved with the spread of the sewerage system after 1885. According to one informed commentator, the city's water catchment area prior to 1888 , the Botany swamps, was "liable to pollution from many sources, and the district of Botany itself has been for many years a hot bed of diarrhoea and typhoid fever." 15 In fact, the growth of Sydney outpaced the capacity of the water supply and the adequacy of sewage disposal facilities. ${ }^{16}$ Only when the

18 J. H. L. Cumpston and F. McCallum, The history of intestinal infections in Australia, 1788-1923, Melbourne, Govt. Printer, 1927, p. 9.

${ }^{14}$ Another important factor working to reduce the infant death rate was the decline in average family size in this period. During the fifteen years from 1888, there occurred a decline in the crude birth rate in Australia as marked as that of any Western country, except France, in the modern period. The average completed size of family in 1891 was seven children. In 1891-1911 it was only five, and for families started in 1911 it was somewhat below four. N. Hicks, 'Evidence and contemporary opinion about the peopling of Australia 1890-1911', Ph.D. thesis, Australian National University, 1971, pp. 268-269.

15 Armstrong, op. cit., note 11 above, p. 392.

${ }_{16} \mathrm{M}$. W. Flinn has pointed to the continuing pressure of population growth on sanitary conditions in British towns from the mid-nineteenth century: "Had these towns been equipped .... with efficient sewerage and cleansing services and adequate water supplies, their disproportionately fast growth during the third quarter of the nineteenth century would not necessarily have exacerbated the public 


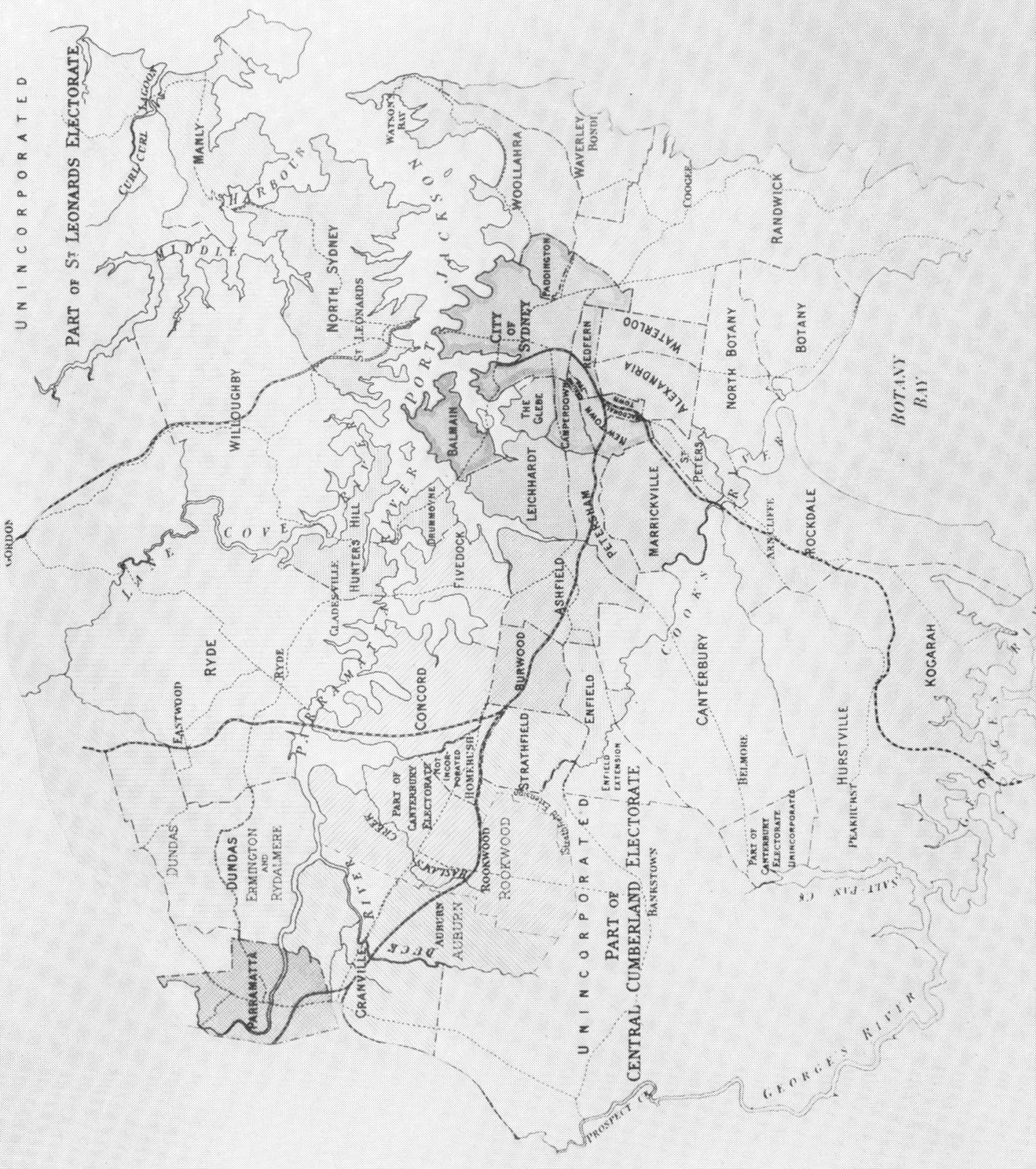




\section{Sanitation, intestinal infections, and infant mortality in late Victorian Sydney}

sanitary condition of the city reached crisis point did the authorities take action to provide adequate systems. In the period 1871-1891, Sydney experienced a spectacular growth of population. It had an average annual growth rate of five per cent in the first decade and 5.5 per cent in the second decade. Such a rate of population growth was not attained again. ${ }^{17}$ The population expanded from almost 138,000 people in 1871 to just over 383,000 people in 1891 . The suburbs enjoyed a notable growth, particularly in the 1880 s, when their average annual increase was 8.25 per cent, against the City's 0.7 per cent.

The metropolitan area grew spatially as well. From the 1880 s there was a great expansion in urban railway construction: Sydney, like other Australian cities about this time, ceased to be a "walking" city and became a "public transport" one. ${ }^{18}$ Until the 1880s, except for some areas in the eastern suburbs and North Sydney, suburban development remained near to the only railway line, the line to Parramatta, which had opened in 1855. During the 1880s the lines from Strathfield to Hornsby and from the city to Sutherland were finished. In the 1890s the line from Milson's Point to Hornsby and that from Sydenham to Belmore were completed. So by the mid-1890s most of the suburban railway system was built. Wage-earners could then live in suburbs serviced by the railway and located some distance from the city centre. Steam ferries transported commuters living in harbour-side and nearby areas, and steam trams provided transport to areas between railway lines or to areas unserved by the railway. The first tram ran from Redfern to the city in 1879. Legislation in 1880 provided for construction of tram-lines by the Commissioner of Railways, and links were soon constructed to the eastern suburbs of Woollahra, Randwick, and Waverley, and to the nearer suburbs of Waterloo, Newtown, Marrickville, and Glebe. The tramway system continued to grow rapidly up to World War I. The end-product of the two decades of remarkable growth was that "Sydney in 1891 was a metropolis by world standards and proud of it, accepting only London as its superior". ${ }^{19}$

The pattern of Sydney's growth in the later nineteenth century has been described in terms of concentric zones, the symmetry of the model being modified in reality by the shape of the harbour and by the hilly terrain. It was further complicated by the siting of industry and the actions of land developers. Later, the pattern was modified by the ribbon development associated with suburban railway lines and the interstitial development made possible by the tramways and omnibuses. As Sydney grew, the commercial and administrative core expanded and working-class residents were pushed into the previously fashionable surrounding areas: "The wealthy moved far away or retreated to elite enclaves, whilst the middle class pioneered each outskirt suburb, then in turn moved on". ${ }^{20}$

health problem." Introduction to A. P. Stewart and E. Jenkins, The medical and legal aspects of sanitary reform, Leicester University Press, 1969 (first published in 1866), p. 8.

17 J. R. Davis and P. Spearritt, Sydney at the Census 1971: a social atlas, Canberra, 1974, p. 8.

$18 \mathrm{~J}$. W. McCarty, in C. B. Schedvin and J. W. McCarty (editors), Urbanization in Australia. The nineteenth century, Sydney University Press, 1974, pp. 16-17.

${ }^{10}$ E. C. Fry, in R. S. Parker and P. N. Troy (editors), The politics of urban growth, Australian National University Press, 1972, pp. 7-9. Davis and Spearritt, op. cit., note 17 above, pp. 6, 9.

${ }^{20}$ Fry, op. cit., note 19 above, p. 6. 


\section{Milton Lewis}

By the 1890 s, then, a pattern of residential zoning was established. There was an inner area of working-class housing from the Rocks around Darling Harbour to Pyrmont, Camperdown, Redfern, Surry Hills, Paddington, and Woolloomooloo. Glebe and Balmain were in the process of being included in this heavily populated zone. Less populous suburbs surrounded this inner area: Leichhardt, Petersham, Marrickville, St. Peters, Alexandria, and Waterloo. This area extended down the western railway line to include Ashfield and Burwood, and down the southern line through St. Peters into Rockdale. The more well-to-do wage-earner lived in this second area. The prosperous and the wealthy lived on the peninsulas and bays as far as the South Head, in the suburbs east of the inner zone, or in exclusive areas some distance from the centre like Strathfield or Hunter's Hill. ${ }^{21}$

Even before the sanitary condition of Sydney was shown to be critical in the mid-1870s, attention had been drawn a number of times to the worsening condition of the environment and the threat posed to the health of citizens. In the later 1850s the Philosophical Society concerned itself with the sanitary condition of the city, appointing a committee to investigate the matter in 1856. The appointment of a City Health Officer was considered to have made the committee's work superfluous. Soon afterwards, a select committee, enquiring into the condition of the metropolitan working classes, focused attention on various sanitary defects. Witnesses pointed to the poor personal hygiene of working-class people and blamed it on the difficulties they faced in getting readily available water in the home. The administrators of the water supply had gradually withdrawn street fountains to force connexion of houses to the water mains. But many owners of poorer-class houses, already receiving high rents, refused to make such improvements. The committee was told sewerage facilities in the city area were poor. Of 1,446 houses inspected, only 356 had water closets. ${ }^{22}$

The suburbs developed in the 1860s without a parallel growth in water main connexions, and tanks and wells were extensively used in suburban areas. In response to public concern over the capacity of the existing water supply to meet a growing demand, a commission of enquiry was appointed in 1867 to recommend a reliable, alternative source of supply. After two years of taking evidence, the commission finally recommended the Upper Nepean scheme. Dispute raged over this choice. Meanwhile the sanitary state of the city grew worse. In 1870 a Sydney doctor, calling for public health reforms, said Sydney displayed the same environmental evils as cities of comparable size overseas. ${ }^{23}$ Early in 1874 Professor Archibald Liversidge revealed to the public that his analysis of water as supplied to the Union Club in the City showed the liquid to be "filthy and unfit for use". About the same time a series of articles was published in the Sydney Morning Herald showing how unfit the Botany watershed was for the collection of the city's water. ${ }^{24}$

${ }^{21}$ Ibid., p. 7.

22 Select Committee Report on Condition of Working Classes of Metropolis, 1860, pp. 32-38, Votes and Proceedings. N.S.W. Legislative Assembly, vol. 4, 1859-60. D. L. Clark, 'The development of Sydney's water supply, 1842-1887', Hons. thesis, Sydney University, 1967, pp. 136-137.

${ }^{23}$ A. M. Brown, N.S.W. med. Gaz., November 1870, pp. 33-40.

24 Ibid., February 1874, p. 160; April 1874, p. 219. 


\section{Sanitation, intestinal infections, and infant mortality in late Victorian Sydney}

The condition of sewerage facilities was just as parlous. The New South Wales Medical Gazette, the colony's medical journal, claimed many cesspools in the city had not been cleaned out for ten to twenty years. Overflow from cesspools was a considerable and constant nuisance. Calling for reform in 1874, the medical journal remarked that ". . . the various emanations" were "of so unpleasant a character, that one sniff of them by a sensitive nose is sometimes enough to cause headache". ${ }^{25}$

Public concern about sanitary conditions finally forced the legislature to act, and a board of enquiry was established in 1875. The Medical Gazette welcomed the investigation. It added that it believed typhoid was commonly being spread in Sydney because fluid from cesspools was seeping into the shallow wells which were so common in the suburbs. One contributor to the Gazette, Dr. S. T. Knaggs, suggested the deaths of a Governor, a couple of Ministers of the Crown, and a few senior city officials might be needed to elicit reforms. ${ }^{26}$

The first revelations of the Sewage and Health Board, established in 1875, were devastating. It revealed that 4,700 of Sydney's 5,400 water-closets were directly connected with the water mains in such a way that household drinking water could easily be polluted by sewage. An inspector of nuisances told the enquiry of his visit to a house in Castlereagh Street, City, where he found the water-closet blocked. Drawing a tumblerful of water from a tap in an adjoining yard used for household purposes, he found it contained solid faecal matter. The Board warned that similar accidents could well be common. The Board called for immediate legislative action to empower the City Council to cut off water where such defective connexions existed. ${ }^{27}$ The Water Pollution Prevention Act was hurried through Parliament. It required correct fittings to be installed within one year of the passing of legislation. In its second report the Board drew attention to another sanitary problem demanding immediate action. This was the management and emptying of cesspits in the City and suburbs. The Board said the municipal authorities appeared to have little power to regulate such matters. It recommended that councils be given the duty of cleaning out cesspits, and the legislature passed the Nuisances Prevention Act, 1875, which required councils to assume this responsibility. The Act also required them to employ inspectors of nuisances.

The Board concerned itself as well with overcrowded areas and dwellings, filthy premises, deficient drainage, and refuse disposal, cowyard nuisances, and other sanitary problems. Its committee on crowded dwellings and areas reported that the worst type of overcrowding was found in "closely packed rows of small badly-constructed tenements at the back of large dwellings and in courts and lanes leading out of the main streets". Houses unfit for habitation were found to be "unfortunately very numerous in Sydney". ${ }^{28}$

This, of course, must have had an important bearing on domestic hygiene in the prevention of infant diarrhoeal disease and infant mortality. For many poorer

25 Ibid., May 1874, p. 252.

26 Ibid., July 1875, p. 298, March 1875, p. 142.

27 Progress report. Sydney City and Suburban Sewage and Health Board, 1875, pp. 5, 7, Journal N.S.W. Legislative Council, vol. 25, 1875.

${ }^{28}$ Eleventh Progress Report, 1876, pp. 6, 8, Journal N.S.W. Legislative Council, vol. 25, 1875. 


\section{Milton Lewis}

working-class families living in the inner-city area in the nineteenth and early twentieth centuries, it must have been very difficult, even where the resolve was strong, to maintain a reasonable level of hygiene. In the inner city of the early 1860 s many dwellings consisted of just two rooms; they were grossly overcrowded, and lacked bathing and washing facilities. One observer, Robert Fitzgerald, M.L.C., said "if you go down some of the places, you are obliged to put your handkerchief to your nose, the smell is so bad". Even better cottages lacked indoor sinks, fitted pantries, suitable stoves, and clothes' closets. Unable to maintain cleanliness in such conditions, the average mother could scarcely care for her children adequately. ${ }^{29}$ No improvement in the housing of the inner-city poor had taken place by the end of the century. Some of the tenements off Gloucester Street, Church Hill, were described by a commission of enquiry in the late 1890s as follows: "Hart's Buildings consist of about sixteen, more or less dilapidated tenements in a confined, low-lying dirty square, which is the common yard of the neighbourhood .... The square was like a vault. In summer it must resemble a furnace." Writing in 1901, Dr. W. G. Armstrong said of Sydney's worst housing: “. . . in a year's public health work in the poorest ... portion of London-Whitechapel-I never came across dwellings in as bad condition structurally as some of those I have seen in Sydney slums. Only that our climate has stood our friend, I cannot conceive how the death rate from phthisis and other preventable diseases has stood as low as it has done, when I think of the damp ill-ventilated, and overcrowded hovels which so many of the people occupied." Further, sewer connexions were often so faulty as to constitute "a serious source of danger". ${ }^{30}$

The Sewage and Health Board suggested that the only solution to Sydney's waste disposal problem was a complete system of underground sewerage. A permanent Board of Health was needed to ensure that municipalities collected refuse and carried out other sanitary duties.

There was no problem in explaining the high death rate in Sydney, the Board concluded. Indeed, it was incredible that epidemic disease had not been more severe. The Board therefore recommended that legislation to establish a Board of Health be speedily enacted and that an adequate sewerage system for the metropolis be built. After some delay both proposals were implemented, although it took another health crisis to bring the Board finally into being.

In 1877 W. Clark, an eminent English civil engineer, brought out by the Government to advise on the city's water and sewerage problems, endorsed the Sewage and Health Board's sewerage scheme. Construction began in 1880. Work also began on the new water supply system, the Upper Nepean scheme. The new supply system was completed in 1888.31 Real estate advertisements in the Sydney Morning Herald now included the words, "Nepean water laid on".32 The construction of the original p. 264.

${ }^{29}$ M. Cannon, Life in the cities. Australia in the Victorian age, Melbourne, Nelson, 1975, vol. 3,

${ }^{30}$ Royal Commission on Public Charities. Second Report, 1898, p. 96, Journal N.S.W. Legislative Council, vol. 58, 1, 2nd sess. 1898, W. G. Armstrong, Australas. med. Gaz., November 1901, p. 462.

${ }^{31}$ F. J. Henry, The water supply and sewerage of Sydney, Sydney, Halstead Press, 1939, pp. 54-55 and 160-161.

32 Clark, op. cit., note 22 above, p. 227. 
sewerage scheme was completed in 1889 , and by the early 1900 s the areas originally to be included in the total scheme were served by the system.

There seems little doubt that by the turn of the century, with a clean water supply established and the main sewerage systems completed, Sydney was a considerably healthier city. The mortality of the city and seven adjacent suburbs from typhoid and diarrhoea in 1889 was 34.8 and 112 per 100,000 of population respectively. In 1897, after completion of the main sewerage systems, the mortality was fifteen and seventyone per 100,000 respectively. The death rate from intestinal diseases had fallen notably. The prevalence of typhoid was markedly reduced as well: in 1897 the eight sewered areas of Sydney had an average of ninety-eight cases per 100,000 of population, while the thirty-one unsewered districts had an average of 171 cases. $^{33}$ That a proper system of sewage disposal and a reliable water supply were desperately needed is shown by the reduction in the deaths from intestinal disease. It is also indicated by the description of sanitary conditions in many parts of Sydney as late as the $1880 \mathrm{~s}$. In 1886 Dr. F. H. Quaife said of the Eastern Suburbs, some of which included the most prestigious residential areas in Sydney, "Even in the higher parts of our suburbs we are met by gutters full of dark, ill-smelling water . . . we are forced to steer along the middle of the street to avoid the odours of the gutter on either side. . . . In some gutters the stench is so peculiar that one cannot help thinking that faecal matters have overflowed. ...."s4

Above all other epidemic diseases, typhoid seemed to threaten Sydney's health, and from the 1880 s sanitarians like Dr. C. K. Mackellar and Dr. John Ashburton Thompson took every opportunity to use the typhoid returns to urge practical and legislative reforms in public health. But smallpox, not typhoid, was in the event the spur to the creation of the first central health authority, the Board of Health, in 1882. In terms of deaths, the smallpox epidemic of 1881-1882 was the most serious ever experienced in Australia. Twenty-six per cent of 154 persons known to have been infected died. Except for two cases, the outbreak did not spread beyond Sydney. ${ }^{35}$ As the infection spread, popular alarm mounted. The government responded by appointing a temporary board of advice. Almost seven months after the epidemic began, the government had the Infectious Diseases Supervision Act, 1881, passed. The act created the Board of Health, which began to function from the beginning of 1882. While it was given powers adequate for coping with the epidemic, it was hardly endowed with powers to deal with the colony's whole range of public health problems. In a cumulative process ending in the Public Health Act of 1896, executive powers were given to the Board of Health. Centralization of control in the Board's hands had much to do with the continuing ineffectiveness of local authorities in public health matters.

Public opinion in Sydney became increasingly critical of the performance of municipal authorities in the health area. In 1885 the public learnt that the City Council had allowed nightsoil to be dumped in close proximity to the watershed of the metro-

\footnotetext{
3s J. Davis, Proc. Instn civ. Engnrs, 1901-02, p. 41. (First proof copy, Pamphlets vol. 149, National Library of Australia.)

${ }^{34}$ F. H. Quaife, J. R. Soc. N.S.W., 1886, 20: 350-352.

${ }^{35}$ W. G. Armstrong, Med. J. Aust., March 1937, p. 401.
} 


\section{Milton Lewis}

politan water supply. When the danger was pointed out by Dr. C. K. Mackellar, the Council grudgingly put an end to the practice. In June 1885 a public meeting at the Town Hall urged the government to introduce a general health bill as soon as possible. . $^{36}$

Later in 1885 C. K. Mackellar, representative of the government in the Legislative Council, introduced a public health bill. Because of a change of government, the bill did not get beyond the first reading stage. Sanitary reformers like Mackellar, Thompson, and Dr. H. N. MacLaurin continued to point to the recurrent typhoid outbreaks as evidence that a public health act was desperately required. In 1886, MacLaurin, when President of the Board, wrote concerning an outbreak of typhoid traced to a Leichhardt dairy, "From the story of this outbreak we can all see the absolute necessity of some form of sanitary legislation ...".37 During a visit to England in 1892-1893, MacLaurin gathered information on sanitary legislation and administration. In a report to the Colonial Secretary of New South Wales, he suggested that a general health act was needed. Yet nothing resulted immediately from MacLaurin's recommendations.

In 1895 the Medical Gazette called for a general health act. Such legislation, it argued, had been responsible for the decline in the general death rate in England and in Victoria, and New South Wales was lagging behind the times. ${ }^{38}$ In September 1896 legislation was introduced by the Reid government. The act, the authorship of which was shared between Ashburton Thompson and B. R. Wise, Q.C., took effect from the beginning of 1897. It conferred considerable power on local authorities for the prevention of infectious disease, the abolition of nuisances, the closing of unhealthy dwellings and polluted water sources, and the taking of action against purveyors of adulterated food. The Board of Health was given the powers of a local authority, and might make enquiries in any matter concerning the public health. The Board, as the central health authority for the colony, occupied a position analogous to that of the Local Government Board in England. Indeed the act followed the main lines of the English public health acts, except for factors relating to local conditions. The Board exercized a supervisory role in relation to the local authorities, only supplanting them in executive matters when they failed to carry out their responsibilities.

The Public Health Act, 1896, provided for the appointment of full-time medical officers of health in the two most populous urban centres in New South Wales: Sydney and Newcastle. In April 1898, Dr. W. G. Armstrong was appointed to the post of medical officer of health for the metropolitan combined sanitary district, while Dr. Robert Dick became medical officer of health for the Hunter River combined sanitary district. The positions were obviously modelled on those so well established in English cities. The first occupants of the posts in New South Wales brought to bear on their work the same skills and attitudes as those so effectively used by their English counterparts.

s6 Australas. med. Gaz., June 1885, p. 224; January 1886, p. 102; July 1885, p. 253.

37 Report on Typhoid Fever in Leichhardt, 1886, p. 5, Journal N.S.W. Legislative Council, vol. 40, 1, 1885-86.

${ }^{38}$ Australas. med. Gaz., April 1895, pp. 167-168. 


\section{Sanitation, intestinal infections, and infant mortality in late Victorian Sydney}

It is clear from the contents of Armstrong's early annual reports that a great deal of his time was taken up with organizing disposal services for excreta and refuse. Despite the extension of the sewerage system, there remained much to be done in order to improve these services. Armstrong's efforts in these directions undoubtedly added to the impact of the sewerage system in improving the sanitary environment of Sydney. Nine years after his dismal picture of the sanitary condition of the Eastern Suburbs presented above, Dr. F. H. Quaife wrote; "There has been of late years a decided decrease in zymotic disease in these boroughs, especially where the sewers are in action, and particularly in the case of enteric fever ... It used to be quite endemic in the denser portions, and most of the cases now occur outside the sewered limits." 39

The sanitary improvement must not be overestimated. In 1898, almost 1,600 cesspits were still in use in Sydney. Only four local authorities operated an interchangeable pail system. Regulations about pails and apparatus were often not enforced. ${ }^{40}$ The disposal of garbage in particular was not very well managed. The opportunities for flies to breed and for other health hazards to flourish were many. Only one municipality, North Sydney, used an incinerator. The City of Sydney still tipped its refuse on waste land near Moore Park. Dumps were commonly used by other local authorities, and, even worse, the waste matter was often not covered systematically. Nevertheless, the early years of the present century saw a good deal of progress. J. H. L. Cumpston dated the beginning of modern sanitary improvement from about the turn of the century: "... . it was only with the commencement of the twentieth century that Australia as a whole developed an informed and sensitive sanitary conscience. Consequently, the history of the intestinal infections has two phases - the nineteenth century of increasing incidence, of explosive manifestations, of general fluctuations and of spasmodic but inefficient control; the twentieth century of progressive and orderly control to a point far below that of any period of the nineteenth century."41

Not suprisingly, the coming of plague to Sydney in 1900 caused a great stir of sanitary activity among local authorities. The first epidemic started in January 1900. Public indifference to Health Department warnings turned into panic with the first fatalities in February-March. A second outbreak began at the close of 1901, and outbreaks recurred until 1909. Plague appeared again in 1921-1922. Armstrong said of the 1900 outbreak, "The citizens needed rousing from a slumber of fancied security and indifference towards their sanitary surroundings. The awakening was a rude one, and produced a panic among the public that can hardly be forgotten.... The warnings of sanitarians, which had been hitherto generally spoken to unheeding ears, began to have weight with the public when illustrated in so forcible and terrible a manner. Public opinion pressed strongly for reforms in the sanitary administration of the metropolitan boroughs, the faulty and backward condition of which had become patent."42

A Board of Health inspection of houses in affected areas of the city revealed a large number in very bad condition. A cleansing operation organized by the Depart-

30 Quoted in Cumpston and McCallum, op. cit., note 13 above, pp. 118-119.

40 Report of Medical Officer of Health to Metropolitan Sanitary Districts, 1898, pp. 2-3.

11 Cumpston and McCallum, op. cit., note 13 above, p. 8.

42 Report of Medical Officer of Health to Metropolitan Sanitary Districts, 1900, p. 1. 


\section{Milton Lewis}

ment of Public Works, involving 3,000 workers, was carried out. To forestall future neglect, the government accepted responsibility for paying half the salaries of sanitary inspectors, in return for which it exercized a veto over appointments and dismissals. Virtually a new sanitary section was created in the City Council administration in 1901. Regular house-to-house inspections were begun, over fifty per cent of dwellings having been found to be defective, usually from faulty drainage. As the use of concrete for rat-proofing became more common, the sanitation of dwellings and business premises in the inner-city area advanced considerably.

Use of concrete for road surfaces greatly reduced the dust nuisance for which Sydney, in the summer, was notorious. The progressive replacement of horse transport by motor vehicles cut down the number of stables and manure accumulations in the city. The fly nuisance was thus much abated. The disappearance of horses from the city played no small part in the great decline in the incidence of infant diarrhoea in Sydney as in other modern cities. ${ }^{43}$ In 1903, to prevent the development of conditions favourable to the breeding of rats, the Health Department drew up a code of by-laws covering stables, cow-sheds, and cattle-sheds for adoption by municipalities. Armstrong complained in 1903 that borough councils showed "a great antipathy to the making of new By-laws" in health matters. Over twenty years later his successor, Dr. J. S. Purdy, was complaining about the failure of local authorities strictly to enforce ordinances concerning stables.44 As a result of the plague epidemic, the Sydney Harbour Trust was created. It was given powers over all wharf areas and harbour foreshores. It carried out renovation work in sections of the Rocks area, an old and very dilapidated part of the City. Another notable improvement in public health at this time was the employment of trained health inspectors. Inspectors of nuisances hitherto employed by municipalities were commonly untrained, their tenure uncertain, and their pay low. From 1898, the new medical officers of health, Armstrong and Dick, conducted regular courses of lectures in sanitary law and practice. The President of the Board of Health, Ashburton Thompson, requested the Royal Sanitary Institute, London, the recognized body in England for certification of sanitary inspectors, to conduct examinations in Sydney. The first examination was held at the end of $1900 .{ }^{45}$ Subsequently, other Australian states and New Zealand instituted such examinations.

The combined effect of the extension of the sewerage system and pressure from the

43 Sir Robert Hutchison placed as much weight on the development of the smaller family, the advent of dried milk, and the disappearance of horse transport, as on organized infant welfare work, in explaining the spectacular fall of infant mortality in urban areas. See Armstrong, op. cit., note 2 above, p. 648. Michael Cannon has drawn attention to the effect of horses on Australian cities: "There were other signs of this deep difference between the texture of the horse era and our own. Practically every house had to have its own stables, trough and hay storage shed, no matter how simple, and their placing helped determine the layout of suburban blocks. The effect was universal. 'For every man who keeps a horse in England, there are, proportionately to the population, ten in Australia', observed Richard Twopeny. To get the full flavour of the age, therefore, one must imagine a million or so horses in Australian cities dropping their manure everywhere - a useful fertiliser for the garden, but tolerable as a health hazard only as long as population density remained low." Cannon, op. cit., note 29 above, p. 53.

44 Report of Medical Officer of Health to Metropolitan Sanitary Districts, 1926, p. 91.

${ }^{45}$ Ibid., 1900, p. 9. 


\section{Sanitation, intestinal infections, and infant mortality in late Victorian Sydney}

central health authorities quickly reduced the number of cesspits after 1900 . In 1913 , J. S. Purdy reported that in all districts not yet sewered the double-pan sanitary service was in operation. The danger of the cesspit is illustrated by the following figures showing the typhoid case incidence per type of disposal service: in 1900 the incidence of typhoid in sewered houses was one in 114, in houses served by pail closets, one in seventy-two, and in those using cesspits, one in thirty-one. ${ }^{46}$ Progress in garbage disposal methods came more slowly. Purdy complained in 1913 it was "very exceptional ... to find any local authority which shews any keenness to tackle this problem. ..." 47

Compared with the period before the construction of a reliable water supply and sewerage system and the creation of a well-armed central health authority, the early years of this century saw a great improvement in the sanitary condition of Sydney. These major sanitary advances largely account for the notable decline in the general death rate from intestinal diseases. But it will be remembered that early in this discussion I drew attention to the fact that the decline in deaths at all ages from diarrhoeal disease lagged behind the decline in typhoid deaths. Improvement in the sanitary environment significantly influenced the rates of both diseases. However, other factors mediated the impact of the diarrhoeal death rate because a very large proportion of the total deaths were those of infants. Elsewhere I have argued that infant welfare work with its emphasis on better nutrition and domestic hygiene importantly affected the diarrhoeal death rate. ${ }^{48}$ Nutrition and hygiene in the home were the mediating factors so far as infants were concerned. J. H. L. Cumpston in the 1920s had suggested very much the same thing. ${ }^{49}$ More modern work strongly supports this view of the aetiology of infant diarrhoeal disease. One recent commentator said of solutions to the great problem of diarrhoeal disease in contemporary, economically developing countries: "Most public health workers currently do not question the propriety or desirability of environmental controls, but rather the priority that should be given to them relative to nutritional and medical care needs ...".50 The authors of a study of infant diarrhoeal disease in some communities of the Third World concluded: "The traditional acceptance of environmental sanitation as a fundamental feature of long-term community control of diarrheal disease is fully justified. Because of the factors involved in the origin of the disease in early childhood, sanitary measures have less direct effect in control of weanling diarrhea than of diarrheas at older ages. The fact is inescapable, however, that for satisfactory control of the diarrheas of early childhood, the sources of infection of the disease must be eliminated; and these are in the diarrheas of older members of the population. Control in this group is primarily through environmental sanitation." 51

I suggest, then, that improvement in the sanitary environment of Sydney in the p. 8.

46 Ibid., 1900 , p. 4. In 1901 , the figures were respectively 1 in 136,1 in 80 , and 1 in 26. Ibid.. 1901,

${ }^{17}$ Report of Director-General of Public Health, N.S.W., 1913, p. 87

${ }^{48}$ Lewis, op. cit., note 9 above, especially chs. 1, 5 and 10.

40 Cumpston and McCallum, op. cit., note 13 above, p. 9.

${ }^{50}$ D. J. Schliessmann, Bull. Wld Hlth Org., 1959, pp. 381-382.

${ }^{51}$ Scrimshaw, Taylor, and Gordon, op. cit., note 8 above, pp. 255-256. 
late nineteenth and early twentieth centuries was a significant, but mediated, cause of the decline in infant deaths from diarrhoeal disease.

\section{SUMMARY}

In the later nineteenth century Sydney, the oldest and, for much of its history, the largest Australian city, underwent a period of very considerable population growth. As it became a metropolis, Sydney experienced the pathologies associated with urban expansion in other parts of the Western world at this time. A high level of infant mortality was one such pathology. An outstanding source of infant mortality in Sydney and in many other Western cities was diarrhoeal disease and associated conditions. It is suggested that this was due to an interaction between infection and poor nutrition on a substantial scale, an infant health problem common in the contemporary Third World. Environmental sanitation was at a scandalously low level in the 1870s, but thirty years later sanitary reform had significantly reduced the general death rates from intestinal infections in Sydney. The impact of improved sanitation on infant diarrhoeal and associated mortality was less direct because of the aetiology of infant diarrhoeal disease. 